\title{
THE INTRA-MONTANE BASINS OF THE MIDLAND ZONE, GEOLOGICAL HAZARDS WITH SPECIAL REFERENCE TO HUMAN ACTIVITIES *
}

\author{
Toran Sharma \\ Department of Mines and Geology \\ Kathmandu, Nepal.
}

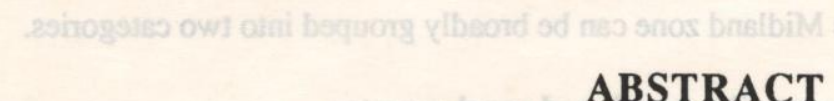

Intra-montane basins of the Midland zone are made up of Pli- Quaternary deposits and are represented by terrace landform which are still on the formative stages. Their geological environment is very delicate and unmindful land utilization could have an unrepairable consequences.

Over the recent years, unmanaged land utilization practices have initiated a series of land degradational processes which are not conducive to the population thriving on the landform. This paper is an attempt to highlight the geological environment of the basins and also to point out how the socioeconomic activities are accelerating the geological hazards.

\section{INTRODUCTION}

The Midland geomorphic zone is characterised by ramifications of low lying hills and valleys. The rivers originating in the Inner and Higher Himalaya drain the zone transversely cutting across all the geological and topographical features. In front of the Mahabharat zone, most of these rivers change their course either to the east or west forming longitudinal valleys until they cut across the Mahabharat range. It is in these transverse and longitudinal valleys that a thick accumulation of plio-Quaternary sediments is seen which cover large surface area on several river basins giving rise to flat terraced topographic forms. These plioQuaternary basins of relatively flat nature are called as intra-montane basins of the Midland zone.

\section{GEOLOGICAL OUTLINE}

The intra-montane basins of the Midland zone are located on the Lesser Himalayan geological province comprising Lesser Himalayan metasediments and Lesser Himalayan crystallines. The Lesser Himalayan metasediments are made up of Precambrian to Tertiary, weakly metamorphosed and unfossiliferous dominantly clastic sequences with locally important carbonate horizons at the top. Precambrian to Middle Palaeozoic, the Lesser Himalayan crystallines, on the other hand, consist of metamorphosed and granitised sequence at the base grading upward into sedimentary sequences comprising argillocalcareous successions.

The succession of the Lesser Himalayan have been complexly thrusted, faulted and folded. Most of the thrust, fault and fold structures align parallel to the Himalayan trend. A few trend across the Himalayan length. Intra-montane basins of the transverse river valleys cut across the Himalayan structures except at Kathmandu

Paper presented in the seminar "Geologic Hazards, Environment and Man Made Structures" on October 7, 1991 in Kathmandu. 
basin and Arun basin. The basins of the longitudinal valleys conform to the fold, thrust or fault structures of the Lesser Himalaya. Some of them are active.

\section{Sediments of the Intra-Montane Basins}

The type sediments of the intra-montane basins show considerable divergence from one basin to the other. Thickness of the sediments not only varies from basin to basin but also within the basin. From the sediment types the intra-montane basins of the Midland zone can be broadly grouped into two categories.

A. Basins comprising coarser sediments like gravels and conglomerates

B. Basins comprising finer sediments like sand, silt and clays.

To the former category are basins of major rivers like Mahakali, Karnali, Gandaki and Kosi. The Kathmandu basin falls in the later category.

The sediments of the major river basins comprise coarse, stratified to unstratified, heterogeneous mixtures of boulders, cobbles, sand and silt. These sediments are poorly graded loosely compacted and indurated. In some basins a part of the sediment cycle is cemented by calcareous matrix.

The studied basins of Kali Gandaki (Fort et al., 1976, Sharma et al., 1980, Yamanaka et al., 1982), Seti at Pokhara ( Horman, 1974; Sharma, 1975; Sharma et al., 1978; and Yamanaka et al., 1982) and Marsyangdi ( Hiroshima, 1972; Yamanaka et al., 1982 and Sharma, 1982) in central Nepal, showed that sedimentation in these basins took place at different times with long intervening periods of erosion. The depositional agents also vary with the sedimentation cycle. Chief depositional agents being fluvial, fluvioglacial and debris flows. In kali Gandaki at least three depositional cycles have been proposed: one of them is a debris flow, the other two are fluvial or fluvioglacial (Yamanaka et al.,1982 and Sharma et al., 1979). In case of the Seti basin (Yamanaka et al., 1982) at least three sedimentary influxes have been noted: one is a debris flow; others are fluvial to fluvioglacial ( Sharma,1975; Gurung, 1970; Sharma et al., 1978 and Yamanaka et al., 1982). Similarly in the Marsyangdi basins two sedimentation phases have been recognised (Yamanaka et al., 1982). One is a debris flow and the other one mostly fluvial. In the other river basins, a similar sedimentation history is anticipated.

Only few of the sediment influxes have been dated in the Seti and Marsyangdi basins. In the Seti basins the youngest sediment influx indicated an age of 1100 to 600 y B.P.( Yamanaka et al, 1982). In case of the Marsyangdi basins the young sediment influx was about 3400 y B.P. ( Yamanaka et al,1982). This indicates that the various sedimentation influxes in the river basins occurred quite independently. In general, it has been seen that the older sediments in all the river basins are partially cemented into conglomerates.

The Kathmandu basin, closed on all sides, comprises sediments exceeding $450 \mathrm{~m}$ in thickness. The northern and the central part of the basin comprise fluvial to fluviolacustrine sediments consisting of sand, silt and clays. In the scuthern part, the sediments are chiefly lacustrine consisting of sticky clays only.

\section{Evolution and Sedimentation of Intra-Montane Basins}

In the Pre-Pleistocene time, as indicated by the valley fills, the main framework of the Himalayan geomorphic zonation was initiated. The zone to the south of present day Himalaya sank in comparison to the 
zones in its north. This brought into existence of the southern and northern mountain chains; the Mahabharata and the High Himalaya with an intermittent subdued Midland zone. A central depression of such nature did not only changed the existing hydrographic system but also deformed the profile of the river courses. As a result, depositional basins were formed in the Midland zone in periods later than Pleistocene. Depositional basins are most pronounced in the areas where the differential uplift is more pronounced as in central Nepal and are very poorly developed in areas of least uplift contrast as in eastern and western Nepal.

Except locally, geological studies did not suggest the difference in uplift between the zones to have taken place along some defined tectonic lines. It seems that the uplift was of relative nature.

The basins of the major rivers seem to have been largely fluviatile comprising coarse gravels and conglomerates. In these basins lacustrine conditions never existed and the rivers were always keeping pace with the changed tectonics by changing their courses and cutting the uplifted southern range. In the Kathmandu basin, lacustrine conditions prevailed right from the Pliocene time till 11000 y B.P.

In the major river basins, the sediment successions suggest that the sedimentation occurred at different times with intermittent periods of progressive toe cutting and terracing. The nature of sediments indicate that the sedimentation was not always purely fluviatile, but has been greatly influenced by debris flow, landslides, fluvioglacial activity and glacial lake outbursts etc. at the river's head waters. Over all, glacial conditions prevailing in the high mountain regions during Pleistocene period has contributed to such an activity. Catastrophic sedimentation is known to occur in the Kali,Seti,and Marsyangdi basins; the last one occurred about 1100 to 600 y B.P. in Seti valley and about 4300 y B.P. in the Marsyangdi valley.

\section{Morphology of the Intra-Montane Basins}

Terrace landform have been characteristically developed in the Plio-Quaternary deposits. The terrace are paired and unpaired and stand at different levels and height form the rivers beds. Two types of terraces have been identified; fill top terraces and fill strath terraces.

Fill top terraces represent the original depositional surfaces where as the fill strath terraces are the product of the river down cutting and migration. At least two fill top terraces have been identified in the Kali, Seti and Marsyangdi valleys ( Iwata et al, 1982 and Yamanaka et al, 1982). These terraces stand at 300m and $260 \mathrm{~m}$ in the Kali Gandaki; $150 \mathrm{~m}$ and 90 to $70 \mathrm{~m}$ in the Marsyangdi valley and 100 to $67 \mathrm{~m}$ and 96 to $60 \mathrm{~m}$ in the Seti valley. The lower fill top surface has buried the terraced topographic forms of the earlier depositions.

In the major river basins, at least 5 to 7 terrace levels have been developed including the fill top terrace levels. Usually the old fill top levels show thick soil development and relatively dissected micro and macro surfaces. In contrast, the fill strath and younger fill surfaces show very thin soil cover, the surface is plain with gentle riverward inclinations. The fill top surfaces are wide in areal extent where as the fill strath surfaces are narrow and are confined to the river valleys.

The terrace break heights vary greatly between the basins. Usually terrace breaks are more than $10 \mathrm{~m}$ and can reach up to $300 \mathrm{~m}$ depending upon the local conditions. The terrace breaks of the old fill top surfaces are generally inclined at angles greater than $45^{\circ}$. The surface itself is dissected by drainages. In the younger terrace surfaces, the terrace breaks are nearly vertical . Dissection, usually not present, but the runoff drainages have cut sharp slit like gullies. 
As for the Kathmandu basins, fill strath terraces, are confined only in a narrow stretch along the principle streams. Fill top terraces are widely developed. At least six different levels of fill top terraces have been identified (Yoshida et al, 1984). The higher fill top terrace are found only in the southern part of the basin. These terraces are comprised of fluvial gravels derived from the southern mountain chains. Three old terraces surfaces of the south stand at heights of 180 to $240 \mathrm{~m} ; 160$ to $180 \mathrm{~m}$ and 120 to $160 \mathrm{~m}$ from the river bed of Bagmati. These terraces were formed after late Pliocene to Early Pleistocene, when the paleo Kathmandu lake was reduced and shifted to the north due to the upheaval of the southern area adjoining the Mahabharat range.

Younger fill top terraces are confined in the northern and central part of the basin. Standing at heights of 80 to $120 \mathrm{~m} ; 50$ to $80 \mathrm{~m}$ and 20 to $50 \mathrm{~m}$ from the Bagmati bed level, these terraces are made up of fuviolacustrine sediments. The youngest fill top terrace was formed about $11,070+290$ y B.P. ( Yoshida et al, 1984).

Distribution of the different geomorphic fill top surfaces in the Kathmandu basin indicates that the lake gradually reduced towards the central part of the basin since Pleistocene. The sedimentation was mostly active in the peripheral zone of the lake and starved relatively in the central and southern part of the basin. With the changing strand lines the deposition shifted towards the centre of the basin forming depositional terraces.

The older fill top terraces standing at heights above $50 \mathrm{~m}$ show micro and macro topographic irregularities due to dissection by surface drainages. The surfaces below $50 \mathrm{~m}$ are flat and undissected. The most extensively developed and utilised for urbanisation are the fill top surfaces of heights 20 to $50 \mathrm{~m}$ and 50 to $80 \mathrm{~m}$ from the river bed.

The terrace breaks between the different fill top surfaces are mostly inclined at less than 30 degree; the break surfaces are smooth but dissected. The terrace breaks between the fill strath terraces on the other hand, are steep and nearly vertical.

\section{Soil Development in the Intra-Montane Basins}

The terrace surfaces of the intra-montane basins show soil at different stages of pedogenesis. The soils in the terraces of the major river basins are largely dependent on

a. age of the terrace surface and

b. climatic conditions in the geologic past.

The old fill top terrace surfaces of Kali Gandaki, Seti Gandaki, Marsyangdi, Trisuli, and Arun show 3 to $4 \mathrm{~m}$ thick red soil grading down into the gravel beds. These soils are mostly the in-situ laterosols formed by a process of laterization under a prolonged hot and wet climatic regime. Iwata et al., 1984, suggested these soils to be very old formed since pre interglacial period.

The soil blanket in the recent terrace surfaces is very thin and is the azonal drift soils deposited over the gravel beds. The thickness of such azonal soil vary greatly in the terrace surface. It is usually thick in areas adjacent to the surrounding mountain slopes.

In the Kathmandu basin, the soils are mostly azonal without structured soil profile. The central part of the basin is made up of fluvio-lacustrine soil where as the peripheral areas consist of colluvium. 


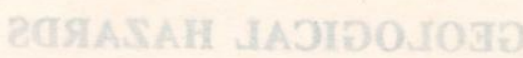

\section{Nature of Surface Water}

Chief surface water sources are the streams and rivers draining the intra-montane basins. In Pokhara valley, substantial amount of surface water is locked in the lakes. The lakes have been formed as a result of the damming of the tributary valleys by the thick gravel deposits of the basin. Such lakes are not seen, at present, in the other valleys, however, conditions similar to Pokhara seems to have existed in the Kali gandaki near Phalebas, and in the Marsyangdi valley in the geological past.

The other sources of surface water are springs fed by ground water. In Kathmandu valley, a number of spring are located near or at the lower surface of the terrace breaks. In other basins, the springs are rare. Since, the river draining the basins have been deeply entrenched to the base of the gravel and conglomerate deposits, spring are located only near the river beds.

\section{Nature of Groundwater}

The type of sediments and their distribution has greatly controlled the groundwater condition of the Kathmandu basin. The northern and central part being made up of fluvial sand and silt with intervening clay horizons,provided good aquifer zones. The southern part comprising of clays only with minor and thin sand and silt horizons, is groundwater deficient.

In general, the piezometric surfaces of the groundwater decrease towards the central part of the valley. The surfaces are located at greater depths in the valley periphery and lie near to the surface in the center. This indicates that the recharge of the groundwater takes along the valley periphery and the groundwater movement is concentrated towards the center of the valley. Recent studies have indicated that the recharge condition in the Kathmandu basins is very poor (Gautam and Rao, 1991). Geological constituents of the valley fill and the buried topographic barriers are thought to be the main constraint of poor recharge conditions.

Total dynamic reserve of the Kathmandu basin is estimated to be $4.61 \mathrm{Mm} 3 / \mathrm{yr}$ or $12630 \mathrm{~m} 3 / \mathrm{day}$. Total static reserve found in the confined aquifers is estimated to be $21.60 \mathrm{Mm} 3$ (Gautam and Rao, 1991).

The basins along the major rivers, on the other hand, has a different story of the groundwater conditions and movements. The coarse gravels and conglomerates are highly potential aquifers. As the rivers have made a deeply entrenched valley in the fill sediments near to the base of deposits, the valley fill materials act as an open system of unconfined aquifers. as a consequence, the rain water and others water recharged from the surroundings mountain slopes are rapidly drained by the gravity to the streams bed leaving little water in the gravels and conglomerate to hold.

A unique feature associated with the groundwater movement in these conglomerate and gravel bed is the under ground erosion Groundwater movement in these highly porous and permeable sediments comprising lime as a main constituent, facilitate formation of underground drainage system is established, the turbulent subsurface water movement causes sub- surface erosion ultimately leading to the formation of underground caves, tunnels etc. 


\section{GEOLOGICAL HAZARDS}

Prime geological hazards are discussed under following headings:

1. Hazards due to catastrophic events:

\section{(i) Debris flows in the head waters of the major rivers}

Excluding the Kathmandu basin, all the other river basins, in the geological past, show evidences of catastrophic events. The basins of Kali Gandaki, Seti and Marsyangdi has records of sediment depositions related to such events. In the Seti river at Pokhara, catastrophic major landslide in the southern slopes of Annapurna affected the entire valley about 1100 to 600 y B.P. (Yamanaka et al, 1982). The debris flow related to this event covered the then existing topographic forms of the Seti river basin. The event also dammed many of the tributary streams forming big lakes around Pokhara. Similar event occurred at the Marsyangdi river about 4300 y. B.P. Debris flow generated in the head waters of the Nyadi khola buried the entire Marsyangdi valley below Bahundanda. In the Kali Gandaki valley, debris flow brought by the Modi khola has buried the paleo topography of the Kali Gandaki below Kusma. The age of the event is not known.

In the recent past small scale catastrophic events of glacial lake outbursts occurred in the head waters of Bhote Kosi, Sun Kosi and Kali Gandaki. Catastrophic landslide occurred in Burri Gandaki, which dammed the river for few hours.

\section{(ii) Earthquake}

In the sediments of the intra-montane basins the earthquake hazards are relatively higher than on the other landform. The Kathmandu basin comprising sand, silt and clay layers in water saturated conditions can react violently to the ground shaking. The shaking causes liquefaction of water saturated sediments such that the liquefied silt and sand are squeezed out in the form of mud volcanoes. Event of this nature occurred in the central part of the Kathmandu basin in the earthquake of 1934.

The hazard due to liquefaction is more in the water saturated zones of central part of the Kathmandu basin. In rest of the basin liquefaction is assumed to be limited, however, ground shaking will be violently intensified.

In the other basins of the Midland comprising coarse gravels and conglomerates in almost water free conditions, the liquefaction effect will be less. The shaking will, however, be violently intensified. Major landslip may be a possibility in the steeply sloping terrace breaks. Landslip events can even take place from the interface of buried topographic forms. Chances of major roof collapses can not be ruled out in the cavernous underground morphology which is characteristic of all the river basins of Midland zone.

\section{Hazards due to down cutting and Lateral migration of the rivers}

River waters are the major causes of land degradation. As a matter of fact, present day terraced topographic forms are due to the legacy of the river action in response to the changing pattern of geodynamic activity. Hence, caution to the river action is always warranted.

In a basin under active river action, sequential events of tectonic uplift and period of quiescence generate terraced topographic forms. Steep topographic breaks reflect the period of active uplift. The terracing is more 
pronounced, if the basins comprises easily erodible materials like those of the intra-montane-basins. The river action need not always be related with the geodynamics, it can even be affected by the human interference.

At present all the rivers of the Midland basins are rapidly down cutting and have narrow river beds. This will affect the terraces lying adjacent to the river bank, where small scale land slip can be generated due to rapid entrenching of the river and formation of vertical wall.

Excessive erosion and degradation of land in the head waters have promoted sedimentation in some of the river basins. This has caused lateral migration of the river and of the terraces lying adjacent to it. This phenomenon seems to exist in the Kosi system of eastern Nepal.

As for the Kathmandu Basin, excessive sedimentation in the northern part of Manahara and Bagmati rivers has caused the low lying terraces to silt and become unsuitable for agriculture.

\section{Hazards due to morphology of the basins}

As described earlier, the landform of the intra-montane basins are characterised by the terraced topographic forms. The wide and flat terraces alternate in sequence with the inclined terrace breaks. The terrace breaks carved on the weakly compacted sediments are geologically the most unstable zones. Acts of gravity and various other slope forming processes are constantly eroding these surfaces. As a result, the terrace break slopes retreat backward until a stable angle is achieved.

The actual hazard zone depends upon the terrace height and the length of the terrace break, but, generally, spreads within a few hundred meters from the terrace breaks. Land failure at the terrace edge is a common incidence. The human activity accelerates the process.

\section{Hazards due to geological make up and structure}

The intra-montane basins are made up of Plio-Quaternary loosely compacted, ill sorted, and weekly indurated sediments. They yield very easily to the different degradational processes and have high erosional potential. Landform built upon them, hence, should be considered largely unstable.

In general, the intra-montane basin deposits have a layered synsedimentary internal structure. Except in the tectonically uplifted areas as in the southern part of the Kathmandu basin, the layers are nearly horizontal. The sediments of the river basins are, often, structureless, however the buried topographic surfaces provide planes of different inclinations.

Since these surfaces are the zone of weakness and zones of differential groundwater movements, they can be of potential hazard.

\section{Hazards due to runoff waters}

The runoff waters can be very hazardous to the terraced surfaces of the intra-montane basins. The sediment being loose, yield very easily to the channelised scouring of surface runoff leading to the formation of rills and gullies. The dissection of the older terrace surfaces are due to the action of such surface runoff. The surface runoff waters are very powerful agents in the valley fill deposits of Kathmandu. In the major river basins, the red soiled old terraces undergo rapid gully formation. 


\section{Hazards due to groundwater}

As described earlier, the groundwater movement in the sediments of the major river basin is causing underground erosion. The formation of caves, underground channels and their widening are done by the percolating underground waters. In the gravel beds comprising lime as a major constituent this process may operate at a grand scale.

\section{Hazards associated with human activities}

Unmindful activities of the man in the Midland basin without understanding the land capability, land's geological make up, the processes operating on the land and the hazards associated with the land system, has accelerated the degradation of land resulting into loss of life, property, ecology and environment. Man's activity in promoting land degradation in the intra-montane basins is discussed below.

\section{(i) Bringing change in the natural drainages.}

Human activities bring about changes in the natural drainages by various ways: construction of roads, houses, diversion of rivers for drinking water, irrigation, electricity generation etc. All of these actions bring changes in the natural drainages and their operating regime. In an under developed country like Nepal, where the planning is at primitive stage, the scale of surface water disruption is maximum and greatly overlooked.

The disruption of natural runoff in the urban areas of Kathmandu has caused many roads to be water logged in the rainy season. The poor sewerage conditions and unmanaged side drains cause heavy surface and subsurface erosion.

In the other river basins, the effect of natural drainage disruption is not to the scale of hazard but the growing civil constructions will bring changes if unmanaged.

(ii) Impact on groundwater conditions

Man is influencing groundwater in various ways. Pumping of groundwater and over watering the surface bring changes in the groundwater conditions.

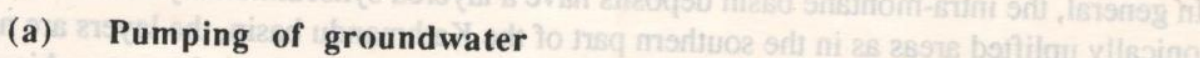

In Kathmandu basin, the existing groundwater reserve is utilised digging deep tube wells in the northern part of the basins. Out of $83,000 \mathrm{~m}^{3} /$ day water supplied in the Kathmandu basin, about $25,000 \mathrm{~m}^{3} /$ day, is pumped from the groundwater resources (Gautam, et al. 1991). This amount of water surpasses the value of total dynamic reserve of the groundwater. If the groundwater exploitation by various industries, hotels and individuals are considered, the situation is more acute.

If this situation is allowed to go unchecked, sagging of the ground will not be far from being. This might endanger civil structures of the valley causing loss of life and property. In the other river basin the situation is not as acute as in the Kathmandu basin. 


\section{(b) Over watering of the ground}

In the urbanised area of Kathmandu, lack of sewerage management has forced the local population to construct septic tanks and soak pits to dispose the household waters. In the clustered area, the number of disposal tanks are so high that they are raising the water table not only endangering the civil foundations but also polluting groundwater.

In the other river basins, the problem is different. Since, these basins comprise highly porous and permeable sediments, the water is rapidly drained underground causing underground erosion. Number of cases of ground subsidence have been reported from these river basins.

\section{(iii) Construction of civil structures on unsuitable land}

As described earlier, the land surfaces of the terrace breaks are the unsafe land units of the intramontane basin. In the Kathmandu basin, at the urbanising centers, all the land units have been utilised for civil construction without giving proper attention to the danger they are prone to. Flood plains of Bagmati and Bishnumati have been utilised indiscriminantly. As a result, the flood waters enter some of the houses at Samakhusi in the wet season.

Similarly, terrace breaks, both gentle and steep have been utilised for construction. Alarming hazards is seen at Baneswor height (the civil structures constructed near the terrace break at Dhobi Khola). The civil structures not only add load to the inclined surfaces but also disrupt the groundwater flow accelerating the land failure. The incidence of Hyumat Tol and Bhaktpur are the result of such unmindful land utilization.

In the other river basin, improper land units have been utilised for construction . In Pokhara valley, the situation is more alarming. In the north central plain of Pokhara, both the banks of seti gorge have been loaded with structures. The toe cutting by the Seti river itself is a great danger to these land units. The recent bridge damage across Seti is the result of unsafe foundation site.

\section{(iv) Mining activities}

In Kathmandu and Pokhara valley, growing need of construction materials has tempted the valley dwellers to mine the valley fill materials and the rocky slopes adjacent to the valley without the knowledge of stability status which has resulted into serious environmental degradation.

In Kathmandu, mining of sand from the river beds has not only changed the hydrological regime of the streams but also lowered their bed levels by about 3 to $5 \mathrm{~m}$. As a consequence, the foundation of bridges are greatly endangered. The bridge connecting Kathmandu with Patan across Bagmati had recently collapsed due to scouring of the foundation.

Similarly, mining of unstable valley slopes for construction material in the southern hill slopes of the basin has initiated a number of landslides, which has not only given an ugly look to the valley surroundings but also caused loss of fertile valley surfaces. Situations in the Matatirtha Pharping, Lele and Godavari area are the result of such activities. Mining activities also caust air pollution, and disrupt the underground water activity. 
The mining as well as the industrial activities have affected a large area in the southern part of the Kathmandu basin.

In Pokhara valley, river bed gravels have been continuously mined. Such activities have even progressed to exposed gravel beds of the terrace breaks causing great loss of the terrace lands.

(v) Waste disposals

In the Kathmandu valley, the conditions of waste disposal are grim. In the absence of sewerage facility, much of the liquid wastes are disposed openly or in septic tanks which are causing pollution of the ground water throughout the valley. The existing sewerage systems are also not functioning properly; leakages are of common occurrence. Similarly, mixing of the sewerage with the drinking water has given a new dimension to the problem.

Again, the constructed sewerage pipes are opened directly on the rivers and streams. Direct disposal of sewerage pipes at Gauri ghat, has polluted the holy place of Pashupati Nath. Situation arising due to the direct sewerage disposal in the streams has made the streams of the Kathmandu basin merely sewerage gutters polluting the entire city. Condition of the pollutants coming out from the industries like leather factory at Bansbari is even worse.

Dry waste disposal at Gokarna and Teku has a similar story due to improper selection of sites.

In Pokhara, inappropriate disposal of wastes is gradually polluting the clean waters of Seti and Phewa Tal. If this continues unchecked, the tourism future of Pokhara could be at stake.

\section{CONCLUDING REMARKS :}

Human role is dual in nature. As a creative agent he can influence the natural processes by understanding and acting according to the ground conditions. On the other hand, he can accelerate the natural processes by unmindful utilisation of land which not only pose threat to his own well being and survival but
also to the very substratum of environment and ecology.

The intra-montane basins of the Midland zone are the sites of rapidly increasing socio- economic activities. In this process, the lands are being utilised without the knowledge of their capability. The results of these activities have endangered the basic environment of the land system. Proper planning of the land operating is a must. To this effect, a thorough study of the land system, their geology, development and operating processes have to be initiated. Further delay in these studies may bring about more irresponsible
land utilisation with related consequences in the days to come. 


\section{REFERENCES}

Fort, M., 1967. Quaternary deposits of the middle Kali Gandaki valley (central Nepal), Himalayan Geology,6,499 - 507.

Gautam, R., and Rao, G.K., 1991. Groundwater potential of Kathmandu valley. Jour. Nep. Geol. Soc., Vol.7, 39 -48.

Gurung, H., 1970. Geomorphology of Pokhara valley, Himalayan Review, Vols II-III, 37 - 49.

Hagen, T., 1969. Report on the Geological Survey of Nepal. Vol. 1: Preliminary Reconnaissance. Denkschr. d. Schweiz. Naturf. Ges., LXXXVI, 1 - 185

Hormamann, K., 1974. Die Terrassen an der Seti Khola - Ein Beitrag Zur Quartaren Morphogenese in Zentral Nepal. Erdkunde, 28, 161 - 176.

Hiroshima, M., 1972, Topography of Marsyangdi River, Symposium: Nepal, 1, 45 - 50

Iwata, S., Sharma, T., and Yamanaka, H., 1984. A preliminary report on geomorphology of central Nepal and Himalayan uplift. Jour. Nep. Geol. Soc., special issue, Vol., 4., 141 - 150.

Iwata, S., Yamanaka, H., and Yoshida, M., 1982. Glacial landform and river terraces in the Thakkhola region, central Nepal. Jour. Nep. Geol. Soc., special issue, Vol.4, 81 - 94.

Sharma, C.K., 1975. Natural resources of Pokhara valley. Navana Printing Works Private limited. Calcutta, 106.

Sharma, T., Merh, S.S., and Vashi, N.M., 1978. The terraced conglomerates of Pokhara Valley in central Nepal. Symposium on morphology and evolution of landform, Department of Geology, University of Delhi, 226 - 240.

Sharma, T., Upreti, B.N.,and Vashi, N.M., 1980. Kali Gandaki gravel deposits of central west Nepal and their neotectonic significance. Tectonophysics, 62, 127 - 139.

Sharma, T., 1982. A cursory note on the Quaternary deposits of Marsyangdi valley and its geomorphic evolution.

Valdiya, K.S., 1987. Environmental Geology Indian Context. Tata McGraw-Hill Publishing Comp. Litd., New Delhi, 583.

Yamanaka, H.,and Iwata, S.,1982. River terraces along the Kali Gandaki and Marsyangdi Khola, Central Nepal. Jour. Nep. Geol. Soc., Vol.2., special issue, 95 - 111.

Yamanaka, H., Yoshida, M., and Arita, K., 1982. Terraced landform and Quaternary deposits around Pokhara valley, central Nepal. Jour. Nep. Geol. Soc., Vol.2, special issue, 113 - 142.

Yoshida, M., and Igarashi, Y., 1984. Neogene to Quaternary lacustrine sediments in the Kathmandu valley, Nepal. Jour. Nep. Geol. Soc., Vol.4, special issue, 73 - 100. 